Preprint, the final version, of the article that has been transferred to the journal's production team.

To cite this article: Ginzarly, M., Houbart, C., \& Teller, J. (2018). The Historic Urban Landscape approach to urban management: a systematic review. International Journal of Heritage Studies. doi: 10.1080/13527258.2018.1552615

\title{
The Historic Urban Landscape approach to urban management: a systematic review
}

In 2011, UNESCO adopted the Historic Urban Landscape (HUL) recommendation and called for the application of a landscape approach to ensure the integration of cultural heritage policies and management concerns in the wider goals of sustainable urban development. This paper tracks the genesis of a landscape approach to heritage conservation, and then presents a systematic review of the literature on the HUL. More than 100 publications from 2010 to early 2018 were analysed. The applied methodology combined an inductive categorization method with a deductive data mining method. The objective is to determine whether the academic discussion is addressing the different dimensions of the HUL approach, including the holistic, integrated, and value-based dimensions, and whether it is progressing through time to move from a conceptual to an operational level. Results show that while the discussion is heavily focused on values, the operationalization of a valuebased approach is still lacking, as it is not fully contextualized in relation to local heritage discourses and the dynamics of heritage governance. Results also show that many case studies applications are in "non-Western" cities, thus opening the debate about the accountability of a value-based approach in contexts that tend to be dominated by groups with the most political power, and where conservation practices mainly focus on the mobilization of material heritage to foster its economic value. Nevertheless, the transition from international guidelines to contextualized local endeavours and policies remains a challenge to be solved.

Keywords: historic urban landscape, heritage conservation, landscape approach, sustainable development, urban governance. 


\section{Introduction}

Since the beginning of the twentieth century, more than 30 standard setting documents and recommendations for the protection and management of cultural heritage have been issued by the United Nations Educational, Scientific and Cultural Organization (UNESCO), the International Council on Monuments and Sites (ICOMOS), and the Council of Europe (CoE). After broadening the scope from monuments to historic centres in the 1960s and 1970s, the concept of heritage was extended to cultural landscapes and cities as living heritage at the turn of the twenty-first century. The expanding notion of cultural heritage to incorporate associative values and multiple perspectives from different stakeholders, rather than a focus on tangible assets and experts' opinions, led to a holistic contextual view of urban heritage to include the concept of landscape (Panjabi and Winter 2009; Bandarin 2015; Taylor 2015). Central to this conceptualization is that landscape, in addition of being a physical entity, is a lived space, a socio-cultural construct, and a mental subjective representation of the environment that changes in time and space (Tress et al. 2001; Gobster et al. 2007; Stephenson 2008; Thompson 2013). The concept of landscape gained currency in the urban planning and development discourses. It started to be part of many disciplines that call for the application of a landscape approach that integrates distinct theoretical perspectives, which are usually discussed separately, to address the complex layering of the various aspects of the landscape (Thompson, Howard, and Waterton 2013), including landscape archaeology (Anschuetz, Wilshusen, and Scheick 2001), landscape urbanism (Mohstafavi and Najle 2004; Waldheim 2006), and landscape ecology (Forman, 1995; Wu and Hobbs 2002). These trends towards a landscape approach to urban management are of great interest to urban conservation as they would allow the integration of cultural heritage in the wider goals of sustainable urban development (Van Oers 2015). In 2005, it was announced by the Vienna Memorandum that the 
evolving notion of cultural heritage requires updated integrative approaches and methodologies for urban conservation and development in a territorial context that could respond to local cultural contexts and value systems (UNESCO 2005). Accordingly, the discussion on the Historic Urban Landscape (HUL) initiative was launched, and in 2011, UNESCO recommended the application of a landscape approach that addresses the city as a whole and integrates heritage conservation within the broader context of urban management.

The specificity of the new UNESCO recommendation on the Historic Urban Landscape (UNESCO 2011) is to combine complementary principles, concepts, approaches, and scopes that were already addressed separately and adopted in previous European and international recommendations and charters. The HUL is not an attempt to replace existing guidelines and policies; instead, it provides a toolkit for the implementation of an integrated value-based landscape approach for the management of cultural heritage. The recommendation provides six critical steps and four tools to adapt this new instrument to local contexts and to facilitate its implementation. Given the interdisciplinary, all-inclusive, and value-based character of the HUL, the biggest challenge remains in bringing all these characteristics together and assembling its components, and in addressing the values of cultural heritage in explicit and unambiguous terms. Seven years after the adoption of the HUL, where does the academic discussion stand today in operationalizing this approach and in adapting its theoretical and conceptual framework to local contexts? This research aims to present a systematic review of the literature on the HUL to (1) underline the transversal character of research published regarding HUL, (2) highlight the missing links vis-à-vis the implementation of the HUL approach, and (3) open the discussion about biases and prospects in the application of the HUL. 


\section{A landscape approach to urban management}

A landscape approach in geographical science may be traced back to the middle of the nineteenth century (Arts et al. 2017). It started to be found more regularly in the heritage discourse since the 1990s (Redford et al. 2003; Veldpaus, Pereira Roders, and Colenbrander 2013). A landscape approach to heritage conservation can be framed within three salient dimensions. First, it is holistic, meaning it addresses the different dimensions of the landscape, including the physicospatial, the mental, and the functional process-related dimensions (Spirn 1998; Terkenli 2001; Tress and Tress 2001). Second, it is integrative in the sense of interdisciplinarity. Landscape is a field that integrates different perspectives across disciplines noting the scientific and humanities approaches as well as cultural and natural heritage perspectives (Tress et al. 2001; Fairclough and Londen 2010). Third, it is value based. In that sense, it emphasizes the engagement and collaboration with communities associated with the landscape to grasp the different values and heritage significance that could support a cross-cultural dialogue between the different stakeholders about the decisions on why a specific asset is of conservation interest (ICOMOS Australia 1999; Mason and Avrami 2002; de la Torre 2005).

It has to be stressed that a landscape approach to urban conservation is the outcome of a long debate within the cultural heritage community.

In 1972, cultural and natural heritage was acknowledged in the UNESCO Convention Concerning the Protection of the World Cultural and Natural Heritage. This convention was a step forward towards a holistic conceptualization of the historic environment, as it defined sites as: "topographical areas, the combined works of man and of nature, which are of special value by

reason of their beauty or their interest from the archeological, historical, ethnological or 
anthropological points of view" (UNESCO 1972, Art. 1). In this definition the socio-cultural relation between humans and their environment in space and across time was recognized as a potential heritage. Later on, in 1992, cultural landscape was recognized by UNESCO as a category of heritage, and afterwards, the European Landscape Convention extended the definition of the notion to go beyond landscapes of outstanding universal values and include all landscapes: the exceptional, the daily life, and the deteriorated. Cultural landscape was defined as "an area, as perceived by people, whose character is the result of the action and interaction of natural and/or human factors" (CoE 2000, Art. 1). In 2003, the Convention for the Safeguarding of the Intangible Cultural Heritage recognized intangible heritage as a mainspring of cultural diversity and a guarantee of sustainable development and defined it as: "the practices, representations, expressions, knowledge, skills - as well as the instruments, objects, artefacts and cultural spaces associated therewith - that communities, groups and, in some cases, individuals recognize as part of their cultural heritage" (UNESCO 2003, Art. 2:2). By that time, a holistic conceptualization of heritage assets was formulated to include not only the tangible aspects of a place but also the practices and experiences of a place accompanied by personal perceptions that result from the human-environment relationship.

The integrated approach to heritage conservation can be traced back to the European Charter of the Architectural Heritage. This charter called for the integration of conservation concerns in regional planning policies and for the application of participatory planning principles for the involvement of different stakeholders (CoE 1975). Later, in 1976, The Nairobi Recommendation Concerning the Safeguarding and Contemporary Role of Historic Areas called for integrating conservation concerns into national, regional, and local planning and for integrating historic centres with contemporary urban life (UNESCO 1976). Ten years later (1985), the 
Granada Convention for the Protection of the Architectural Heritage of Europe came to set the framework for the application of such an approach within Europe (CoE 1985). In 1987, ICOMOS adopted the Washington Charter for the Conservation of Historic Towns and Urban Areas that also called for the implementation of participatory planning and also recommended that multidisciplinary studies be conducted to inform urban conservation (ICOMOS 1987, Art. 5). By the end of the 1980s, an integrated approach to urban conservation started to take shape, and principles and guidelines for its application were developing at the international and European level.

A value-based approach to heritage can be traced back to the beginning of the twentieth century (Riegl 1903), and since the early 1980s, the conservation and management of archaeological heritage has been moving towards a value-based approach (Demas 2002; Poulios 2014, 21). It was not until 1999 that the Burra Charter came to provide a new impulse to the use of this value-based approach by providing guidance for the conservation and management of places of cultural significance (ICOMOS Australia 1999) and defined the latter as the "aesthetic, historic, scientific, social or spiritual value for past, present or future generations" (Art. 1). Afterwards, the Getty Conservation Institute published a series of research reports to advocate and define the value-based approach (Avrami, Mason, and de la Torre 2000; Mason 2002; de la Torre 2005). This approach was an attempt to move the World Heritage concept beyond Western thinking and value systems in the heritage discourse to address different contexts and cultures in Asian, African, and South American countries (Smith and Akagawa 2008), and it was a source of information, for example, for the 1994 Nara Document (UNESCO 1994, Art. 4), the Operational Guidelines for the Implementation of the World Heritage Convention (UNESCO 1999, paragraph 14), and the 2003 Convention for the Safeguarding of the Intangible Cultural Heritage (UNESCO 
2003, Art. 2:1). Afterwards, different standard setting documents started to define principles and strategies for the application of a landscape approach to heritage conservation, including the Vienna Memorandum (UNESCO 2005), the Xi'an Declaration (ICOMOS 2005), the Faro Convention (CoE 2005), and the Valletta Principles (ICOMOS 2011).

With regard to these different charters and conventions, it should be recalled that the HUL is not a new heritage category, but an approach to managing thoughtful change. The HUL "is envisaged as a tool to integrate policies and practices of conservation of the built environment" (Bandarin and Van Oers 2012: xvi), building on a century-long tradition of practice and on the existing set of regulations and policy documents in order to develop a more holistic, integrated, and value-based approach to urban heritage.

\section{Methodology}

The objective behind the analysis is to identify how and to what extent the three dimensions of the landscape approach to urban management are operationalized through the literature. The search for the appropriate literature was an internet-based inquiry that looked for publications using Google Scholar and ScienceDirect. The search term used was "historic urban landscape" in the title and/or keywords. The review considered articles published between 1 January 2010 and 1 March 2018. Accordingly, it covered 103 publications composed of books, book chapters, peerreviewed articles, conference papers, theses, and reviews. The publications were saved in txt format and then loaded into RStudio software to run the statistical analysis. The statistical analysis

of the corpus of documents combined an inductive categorization method with a deductive data mining method.

The first analysis is expertise based and is built on the standard document of the HUL recommendation. It draws on an expertise assessment of the HUL definition and guidelines for 
application, in order to develop pre-established categories that determine the conceptual and theoretical framework of the HUL. It highlights the essence of the HUL and connects its ontology with the epistemology of urban landscape studies, because the HUL is based on theories and concepts from these fields to enable a landscape approach to the documentation and conservation of the HUL. The analysis breaks down and subdivides the key themes of the HUL into three main categories and different levels of subcategories. This subdivision does not look at possible connections between main categories. Instead, it aims at simplifying the complexity of the HUL and framing the discussion in the investigated documents. The main categories do not overlap and are considered exclusive (one term cannot belong to two different categories). After the development of the model, the analysis calculates the frequency of categorical themes in the corpus of documents, and it measures the relative weight of every theme (main category) to the correspondent sum of subcategories in order to reveal the most frequently discussed aspects and topics as well as missing links, lacks, and limitations.

The second investigation is based on a quantitative analysis of the literature. Before starting the text mining analysis, punctuation, numbers, and stop words were removed, and the text content was changed to lower case to ensure consistency. First, the 20 most frequently used terms in the corpus of documents were retrieved. This analysis is useful in contextualizing the discussion within the corpus along with understanding its general scope. Afterwards, publications were grouped by date with an interval of two years, and the frequency analysis was repeated for every two years to highlight, in general terms, the evolution of the academic discussion about the HUL over time. Subsequently, the terms that are important for the analysis among the most frequent ones were identified. Then, an association analysis was conducted to find the words that are highly associated with these terms in the corpus of documents with a correlation of no less than 0.85 . This 
analysis helps find content relationships and word networks within documents, thus highlighting the most recurrent cross-cutting themes and the different entries to the HUL. Finally, a hierarchical clustering by term similarity was developed for the corpus. This analysis calculates the distance between words, then clusters them according to their proximity. The proximity between two terms refers here to the fact that they often appear together in given documents of the corpus. Eventually, results from both investigations were assessed and compared to determine whether the academic discussion is transversal across disciplines and to whether it has moved from a conceptual to an operational level.

\section{Results}

\subsection{Overview and general patterns}

The number of authors in the analysed corpus is 125 , of whom $81 \%$ have 1 publication, $13 \%$ have 2 publications, and $6 \%$ have more than 2 publications. Most of the publications are articles and book chapters (Table 1).

\begin{tabular}{|l|l|}
\hline Document type & Number \\
\hline Article & 50 \\
\hline Book Chapters & 39 \\
\hline Book & 5 \\
\hline Conference Paper & 3 \\
\hline Thesis & 3 \\
\hline Review & 2 \\
\hline HUL recommendation & 1 \\
\hline
\end{tabular}

Table 1. Number of published documents per type. 
There is a conceptual proximity between HUL and cultural landscape (Trindade-Chagas 2011; Taylor 2015, 2016). They offer parallel terminology for the same assets (O'Donnell and Turner 2012; Buckley, Cooke, and Fayad 2016; Rey-Perez and Martinez 2018). About half of the investigated documents refer to the term cultural landscape, and it is used around 340 times in the corpus. The concept of cultural landscape was first introduced as an academic term in the early twentieth century by the geographer Otto Schlüter (Martin and James 1981). It was then promoted and developed by the geographer Carl Sauer in 1925 to be later recognized as a category of heritage in 1992 and in 2000.
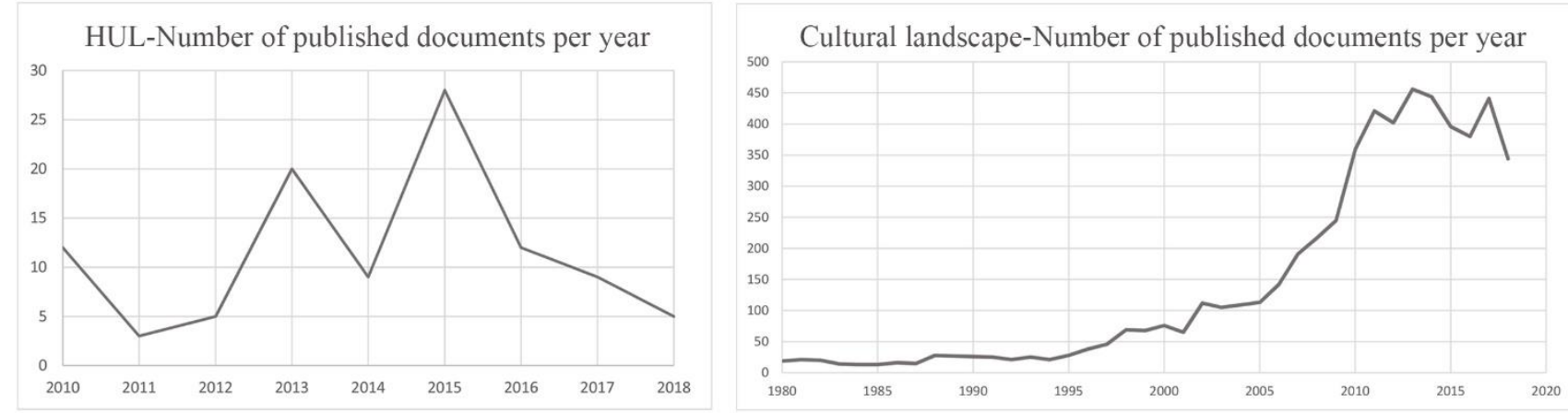

Figure 1. Shows the respective literature production since the concept of cultural landscape and that of HUL were defined. Left, number of published documents per year on HUL (2010-March 2018). Right, number of published documents per year on cultural landscape (1980-March 2018).

It was not until the late twentieth century that the number of publications on cultural landscape started to grow (Figure 1). Publications have grown from 26 in 1990 to 75 in 2000 and to 359 in 2010 and around 440 in 2017 . It therefore took a long period of time for cultural landscape to gain popularity in the academic discussion as well as to be acknowledged as a category of heritage. Accordingly, even though the number of publications on the HUL has not yet exceeded 30 publications per year, this number will most probably grow. This is a question of time, particularly because the HUL is not a concept or a category of heritage like cultural landscape, but an approach. This may initially reduce the contributions of authors and may require 
more time to be developed in academic research. It is also worth mentioning that this research only considers peer-reviewed scientific publications and does not consider a series of conference proceedings. The community is building itself, and around 34 meetings, 6 trainings, and 26 workshops on the HUL were held since the adoption of the recommendation (Siguencia Avila 2018).

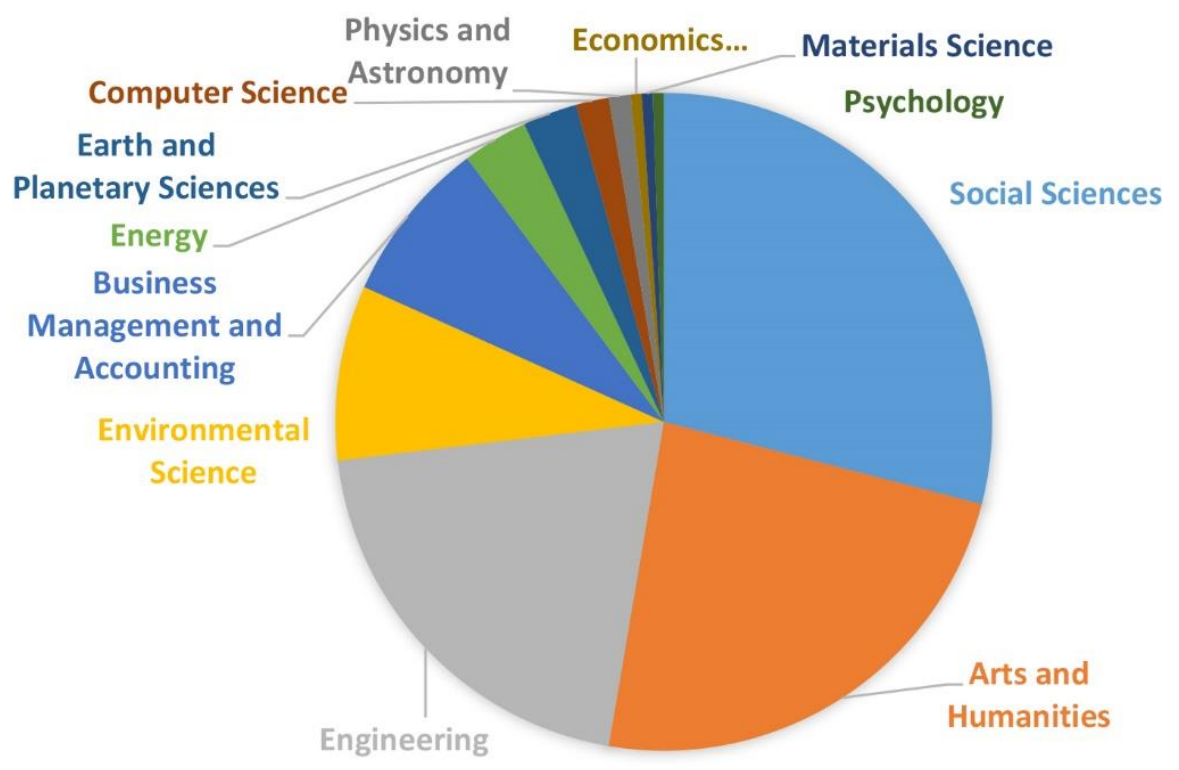

Figure 2. Publications by subject area.

The subject areas of the publications are largely related to social sciences, arts and humanities, and engineering (architectural). Publications within fields such as environmental science, economics, political science, computer science/statistics/big data management, and multidisciplinary studies are still very limited or missing (Figure 2). 


\subsection{Inductive categorization method}

As defined by UNESCO (2011), the HUL goes beyond the notion of the historic centre to include the wider urban context and its geographical setting. This wider context comprises the tangible and intangible attributes and values of urban places, including land use patterns and spatial organization, perceptions, and visual relationships, as well as all other elements of the urban structure (UNESCO 2011, 2016). This definition recognizes non-designated heritage assets and implies that any urban attribute could be a heritage. The focus on cities as living heritage and on community-led endeavours challenges urban planning and development systems (Sykes and Ludwig 2015), and poses increasing complexity around decisions on what attributes and values to protect for future generations in a constantly changing environment. As discussed previously, the HUL (1) suggests a holistic understanding of the historic environment; (2) is an integrated approach that engages with interdisciplinarity; and (3) is value based. These three themes could be identified as entries to the application of the HUL (Figure 3). The developed model displays these main entries and their subcategories (Figure 3, Annex 1). It also shows the total sum of terms under

each main entry within the corpus of documents $(\mathrm{N})$, the equivalent average that is calculated based on the number of subcategories (M), and the number of subcategories (C). 


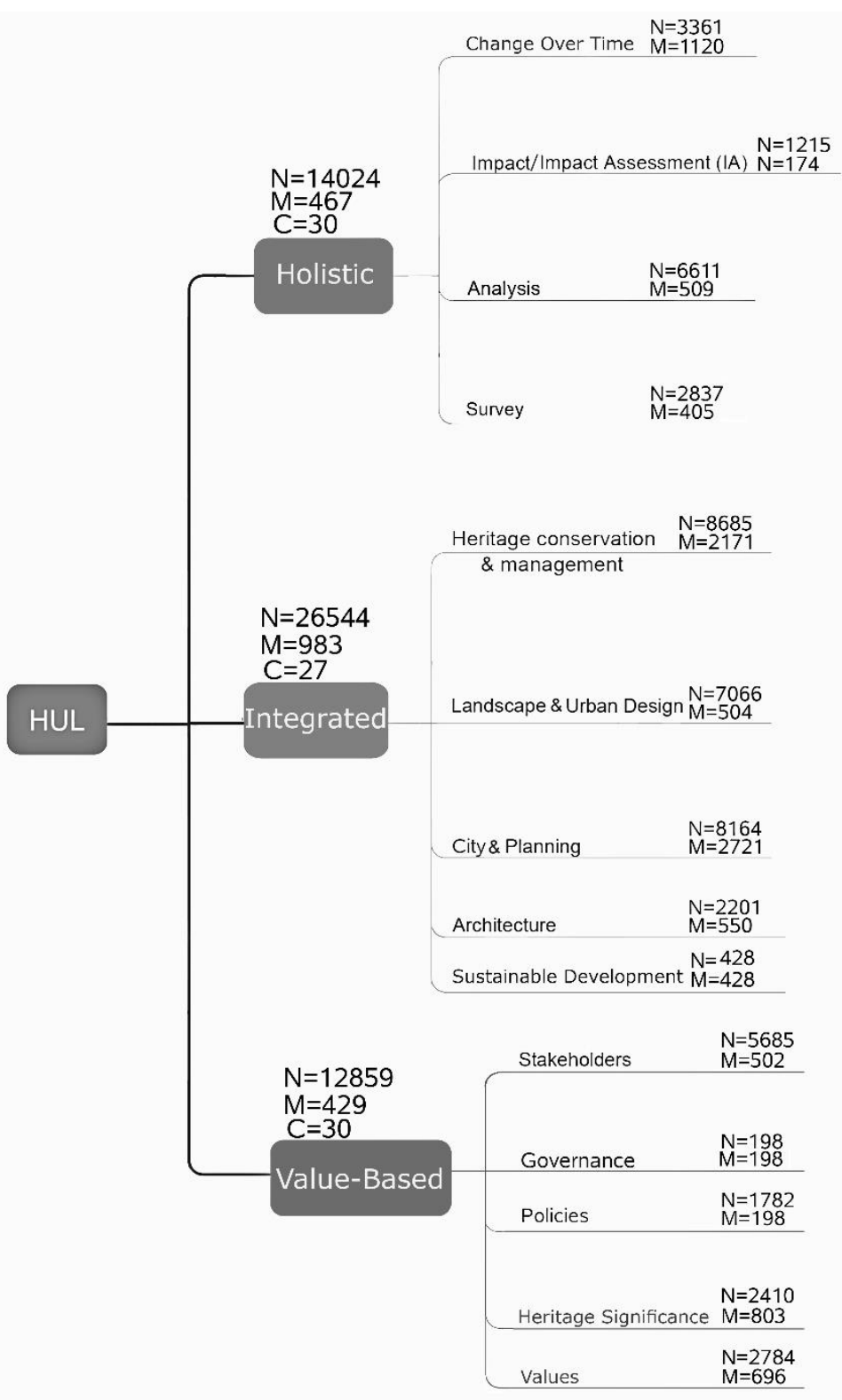

Figure 3. Tree diagram showing the essence of the HUL and the frequency of discussed terms within the corpus of texts.

The results reveal that the most discussed dimension is the integrated one $(\mathrm{N}=26544)$ followed by the holistic $(\mathrm{N}=14024)$ and value-based dimensions $(\mathrm{N}=12859)$. The three dimensions have almost the same number of subcategories: respectively 27,30 , and 30 . Therefore, the fact that there are fewer occurrences of the value-based dimension cannot be related to a less developed conceptualization of this category. As discussed previously, the holistic and integrated dimensions 
for urban heritage conservation started to develop and to be articulated into guidelines for application in international and European conventions earlier than a value-based approach. The latter is still a developing inquiry, as it started to be highly considered in standard setting documents and to gain recognition in academic research in the late twentieth century and early twenty-first century.

The results further reveal that scholars have proposed a diversity of qualitative and quantitative analytical methods to formulate a holistic understanding of HULs. These vary from morphological analysis (Whitehand and Gu 2010; Bianca 2015) to visual analysis (Rodwell 2010), monitoring by means of infrared remote sensing (Ciocia, Napolitano, and Viola 2013), field survey and remote sensing (Aysegul 2016), document analysis and fieldwork to reveal heritage attributes and values (Sanjbod et al. 2016; Ginzarly and Teller 2018), value-based monitoring system (Heras et al. 2013), historical mapping and characterization (Lascu 2014; Bahrami and Samani 2015; Williams 2015), impact assessment (Van Oers 2013; Damen et al. 2013), landscape character assessment (Shamsuddin, Sulaiman and Amat 2012; Dyke et al. 2013), affordance analysis (Alves 2015), digital survey (Masi 2015), GIS analyses (Casatella and Carlone 2013), multimedia survey and 3D modelling techniques (Amoruso and Manti 2016), and multidisciplinary analysis (ReyPerez and Siguencia Avila 2017). This multiplicity of methods is related to the wide scope of the HUL and its multi-layered components that could be addressed through different methodological frameworks. While the historic environment is contextualized as an integral part of the city as a whole, the major problem in regard to this approach is that in many developing countries, there are deficiencies both in the legal framework and management processes to put this into practice (Willems 2014). 
The results also reveal that the academic discussion is heavily focused on the application of an integrated approach that considers heritage conservation and management, urban planning, urban design, and architecture. The discussion enlarges the scope of urban conservation and considers a diversity of disciplines. Still, as Bandarin (2015) argues, these disciplines do not cover the entire spectrum provided by the HUL definition and guidelines for its application, and other practices should be integrated within the discussion about heritage and its conservation, including sociological, anthropological, ecological, and managerial disciplines. These are not very frequent in the corpus, and their contribution still needs to be explored. Moreover, the interdisciplinary field of heritage studies started to be articulated in the 1990s, so the characterization of heritage as a technical process still remains strong and continues to shape practice (Smith 2007). So, as the discussion about the nature and management of heritage keeps moving forward, in-situ applications need to catch up with the speed of these developments.

In addition, the results indicate that even though the discussion about values is intense, it remains generic. The diagrams show that the term values was used around 2800 times in the corpus of documents, whereas notions like cultural value, natural value, economic value, social value, aesthetic value, ecological value, historic value, age value, political value, scientific value do not exceed 300 occurrences (Figure 3, Annex 1). The direction towards a value-based and peoplecentred approach to heritage management is not only challenging because of the mutable and contested character of heritage (Graham 2002; Demas 2002), but also because of the lack of civic engagement and the dominance of centralized planning in many Asian and African countries (Winter and Daly 2012; Chapagain 2013). This fact leads local governments towards the application of implementation processes that go against the spirit of international conventions (Logan 2012). With the existence of many studies on the implementation of the HUL in "non- 
Western" countries, a value-based approach remains critical if it fails to assure equity and stakeholder involvement and to avoid the dominance of values that represent groups with the most political power. The corpus of texts shows that the implementation of the HUL has been applied in different contexts, including Asia (Hosagrahar 2013; Van Oers and Pereira Roders 2013; Rogers 2014; Wang 2014; Ching Fu 2016; Verdini, Frassoldati, and Nolf 2017; Widodo, Wong, and Ismail 2017), Africa (Heathcott 2013; Van Oers 2013; Pereira Roders 2013; Weiss 2014), Latin America (Hill and Tanaka 2015; Rey-Perez and Siguencia Avila 2017; Rey-Perez and Martinez 2018), North America (Jessiman 2015), Australia, Ballarat (Dyke et al. 2013; Buckley, Cooke, and Fayad 2016; Murphy, Dahlhaus, and Thompson 2016 ), and Europe (De Rosa and Di Palma 2013; Bonfantini 2015; Veldpaus 2015).

The academic discussion is concentrated on the conceptual framework of the HUL, while the way forward to operationalize it is still at its early phase in terms of providing innovative methods to grasp the multiplicity of heritage value typologies, reach consensus on what to protect, assess vulnerability to change, and prioritize actions. The term consensus was repeated 108 times whereas vulnerability 148 times and operationalizing and its related terms appear around 220 times. Nevertheless, notions such as management framework and development framework appear only around 20 times. Some scholars have elaborated on a particular application of the four tools proposed by UNESCO to make the HUL approach operative, including civic engagement (Smith 2015; Ragozino 2016), knowledge and planning (Hosagrahar 2015), regulatory systems (O’Donnell 2015), and financial tools (Rypkema 2015; Ragozino 2016). 


\subsection{Deductive data mining method}

\subsubsection{Frequency of terms}

The frequency analysis shows that among the first 20 most frequent terms, 14 terms appear in all the investigated years, and only 8 terms appear once (Table 2). The results reveal that the HUL is transversal across disciplines. Four fields appear in almost all documents: conservation, development, management, and planning. The discussion about urban cultural heritage attempts to bring together disciplines that are usually discussed separately. It also emphasizes values as well as historic, socio-cultural and economic dimensions of heritage. The results moreover show the occurrence of "Ballarat", most probably because in 2013 it became a pilot city for the implementation of the HUL recommendation in Australia.

\begin{tabular}{|c|c|c|c|c|}
\hline Corpus & $2010-2011$ & 2012-2013 & 2014-2015 & 2016-March 2018 \\
\hline UNESCO* & UNESCO* & UNESCO* & UNESCO* & UNESCO* \\
\hline HUL* & HUL* & HUL* & HUL* & HUL* \\
\hline Heritage* & Heritage* & Heritage* & Heritage* & Heritage* \\
\hline Urban* & Urban* & Urban* & Urban* & Urban* \\
\hline City* & City* & City* & City* & City* \\
\hline Conservation* & Conservation* & Conservation* & Conservation* & Conservation* \\
\hline Development* & Development* & Development* & Development* & Development* \\
\hline Management* & Management* & Management* & Management* & Management* \\
\hline Planning* & Planning* & Planning* & Planning* & Planning* \\
\hline Landscape* & Landscape* & Landscape* & Landscape* & Landscape* \\
\hline Values* & Values* & Values* & Values* & Values* \\
\hline Cultural* & Cultural* & Cultural* & Cultural* & Cultural* \\
\hline Historic** & Historic* & Historic* & Historic* & Historic* \\
\hline Social* & Social* & Social* & Social* & Social* \\
\hline Local $^{4}$ & Areas $^{4}$ & Local $^{4}$ & Local $^{4}$ & Local $^{4}$ \\
\hline Areas $^{4}$ & Buildings $^{3}$ & Areas $^{4}$ & Areas $^{4}$ & Ballarat $^{4}$ \\
\hline Ballarat ${ }^{4}$ & International $^{2}$ & Ballarat ${ }^{4}$ & Ballarat $^{4}$ & Economic $^{3}$ \\
\hline Economic $^{3}$ & Concept $^{1}$ & Buildings $^{3}$ & Buildings $^{3}$ & Community $^{2}$ \\
\hline Community $^{2}$ & Time $^{1}$ & Economic $^{3}$ & International $^{2}$ & Sustainable $^{1}$ \\
\hline Approach $^{2}$ & Human $^{1}$ & Approach $^{2}$ & Town $^{2}$ & $\mathrm{Web}^{1}$ \\
\hline Policies $^{1}$ & Protection $^{1}$ & Town ${ }^{2}$ & Environment $^{1}$ & Data $^{1}$ \\
\hline
\end{tabular}

Table 2. Most frequently used terms in the corpus of texts and in publications with an interval of two years from 2010 till March 2018. * refers to terms that are most frequently used in all years. 1 refers to terms that appear in one column (one time interval) in the table. 2 refers to terms that appear in two columns as so forth. 
The table shows that the academic discussion did not progress much over time, and that it is still centred on specific aspects of the HUL. Few changes could be highlighted among the investigated years. For instance, between 2016 and 2018, terms like sustainable, web, and data replace concept, time, human, and protection from 2010 and 2011. In the early discussion about the HUL, authors would refer to the different conventions for the protection of cultural heritage that led to the development of the HUL (Smith 2010; Rodwell 2010; Trindade-Chagas 2011). They also refer to the broadening concept of cultural heritage that considers the whole landscape as an integral entity manifested in time and space by complex human cultural interaction with the environment (Gabrielli 2010; Rodwell 2010; Smith 2010; Van Oers 2010; Markevičienè 2011).

Apparently, academic research is moving from the focus on the conceptual framework of the HUL to discuss the documentation and characterization of the HUL. Scholars are starting to address big data and data layering with Arc Map and GIS (Angrisano et al. 2016; Aysegul 2016; Siguencia Avila and Rey-Perez 2016; Dhingra, Singh, and Chattopadhyay 2017; Rey-Perez and Siguencia Avila 2017), and how to make increasing use of digital technologies, such as web 3.0 and semantic web with regard to the interpretation of assets related to the HUL, such as historic architecture and public spaces (Amoruso and Manti 2016; Bolici, Gambaro, and Giordano 2017). Moreover, some scholars explored the role of web portals and open data platforms in fostering civic engagement, democratizing heritage, and maximizing the scope of datasets to ensure inclusion (Murphy, Dahlhaus, and Thompson 2016; Taylor 2016; Nocca 2017; Widodo, Wong, and Ismail 2017). In the last two decades, remote sensing technologies, ground and aerial technologies, and GIS-based models have successfully been applied to several cultural heritage applications, and they have been considered as ideal tools for analyzing spatial data for the management of knowledge on cultural heritage and for supporting decision-making (Rinaudo, 
Agosto, and Ardissone 2007; Robinson et al. 2010; Agapiou et al. 2015). Moreover, in recent years, crowdsourcing and social media metadata have been recognized by many cultural heritage institutions and scholars as tools for participatory heritage praxis that would allow a variety of encounters and a cross-dialogue between different stakeholders, as they provide community-based platform for communicating users' interaction with cultural heritage (Terras 2011; Giaccardi 2012; Ole and Smith 2012; Liew 2014; Ginzarly, Pereira Roders, and Teller Forthcoming).

There is an agreement among scholars in the corpus about the four pillars of sustainable development: environmental, economic, social, and cultural sustainability. Nevertheless, sustainability is used by most scholars as a concept. The notion of sustainability remains ambiguous as it is not commonly discussed in relation to local policies and urban governance. The frequency analysis reveals that governance appears around 200 times in the corpus. The HUL approach addresses policy, governance, and management concerns involving a diverse crosssection of stakeholders from local to international actors in the urban development process. The HUL implies the application of traditional and innovative civic engagement tools, which constitute an integral part of urban governance dynamics, adapted to local contexts to facilitate intercultural dialogue between groups with conflicting interests in order to promote sustainable development (UNESCO 2011). Scholars have, however, addressed concerns related to the Janus face of innovative arrangements of "governance-beyond-the-state", given that participation is consistently mediated by power, and given the conditions in which the democratic character of the political sphere is affected by the encroaching imposition of market forces that set the "rules of the game" (Getimis and Kafkalas 2002; Swyngedouw 2005). Accordingly, the way forward from an international framework to local sustainable innovations lies in the multiple spheres and dynamics 
of urban governance in respect to decision-making powers of the central state, local community interests and concerns, and local, national, and international non-governmental organizations.

The interpretation and the implementation of the HUL would largely differ from one context to another, as it would be shaped by different forms of urban governance and institutional and social capacities. Few authors have addressed the multiple dimensions of the sustainability paradigm in an explicit way and vis-à-vis urban governance, or in relation to the specific social reality of local context, or of existing policies (Girard 2013; Veldpaus and Pereira Roders 2017; Verdini, Frassoldati, and Nolf 2017; Gunay 2018; Potdar, Namrata, and Sami 2018; Ripp and Rodwell 2018). Moreover, Casini (2017) critically assessed the multifaceted relationship between nationalism and UNESCO international regulations for the protection of cultural heritage. To substantiate the operational dimension of the HUL, future research needs to address, to a greater extent, the different levels of governance, the tension between universal and national norms, and the procedural and discursive issues in the process of achieving sustainability.

\subsubsection{Association analysis}

The association analysis looked for the terms that are associated with three themes: HUL, heritage, and landscape, and four disciplines: conservation, management, development, and planning. The association analysis set a threshold at a coefficient equal to 0.85 because at 0.8 , it found more than 20 associations and in some cases more than 90, which makes the reading of results irrelevant and because at 0.95 and 0.9 , HUL and landscape do not have association rules (Table 3). The analysis explored the results of the first level of association rules, meaning the one that has the higher coefficient, and that was then subjected to a more in-depth investigation on conservation. 


\begin{tabular}{|l|l|l|l|l|l|l|}
\hline & 0.95 & 0.9 & 0.85 & 0.8 & 0.75 & 0.7 \\
\hline HUL & 0 & 0 & 7 & 20 & 31 & 42 \\
\hline heritage & 3 & 11 & 34 & 63 & 112 & 163 \\
\hline landscape & 0 & 8 & 22 & 53 & 86 & 106 \\
\hline conservation & 4 & 24 & 55 & 93 & 120 & 125 \\
\hline management & 6 & 16 & 20 & 46 & 65 & 101 \\
\hline development & 2 & 24 & 62 & 100 & 118 & 130 \\
\hline planning & 2 & 8 & 42 & 93 & 131 & 150 \\
\hline
\end{tabular}

Table 3. Number of terms associated with the investigated themes/disciplines and the corresponding coefficient.

The results show that landscape is highly related to its temporal dimension and continuously changeable character through terms like continuous, historic, period, change, time, and ancient, and also to its natural dimension (Figure 4). Some authors addressed the notion of landscape as a spatial and mental entity, and as an ecological system characterized by complex reciprocal relations among landscape configuration, landscape function, and change. They looked at the relation between structural features and ecological processes and human-landscape interaction/landscape perception (Bahrami and Samani 2015; Smith 2015; Taylor 2015; Murphy, Dahlhaus, and Thompson 2016; Rey-Perez and Siguencia Avila 2017). This result reveals the focus of the discussion, but it does not mean that scholars do not consider the different dimensions of landscape. It is worth mentioning that scholars must be selective and focus on one or specific aspects of their research in academic publications. This fact may sometimes limit the scope of published research. 


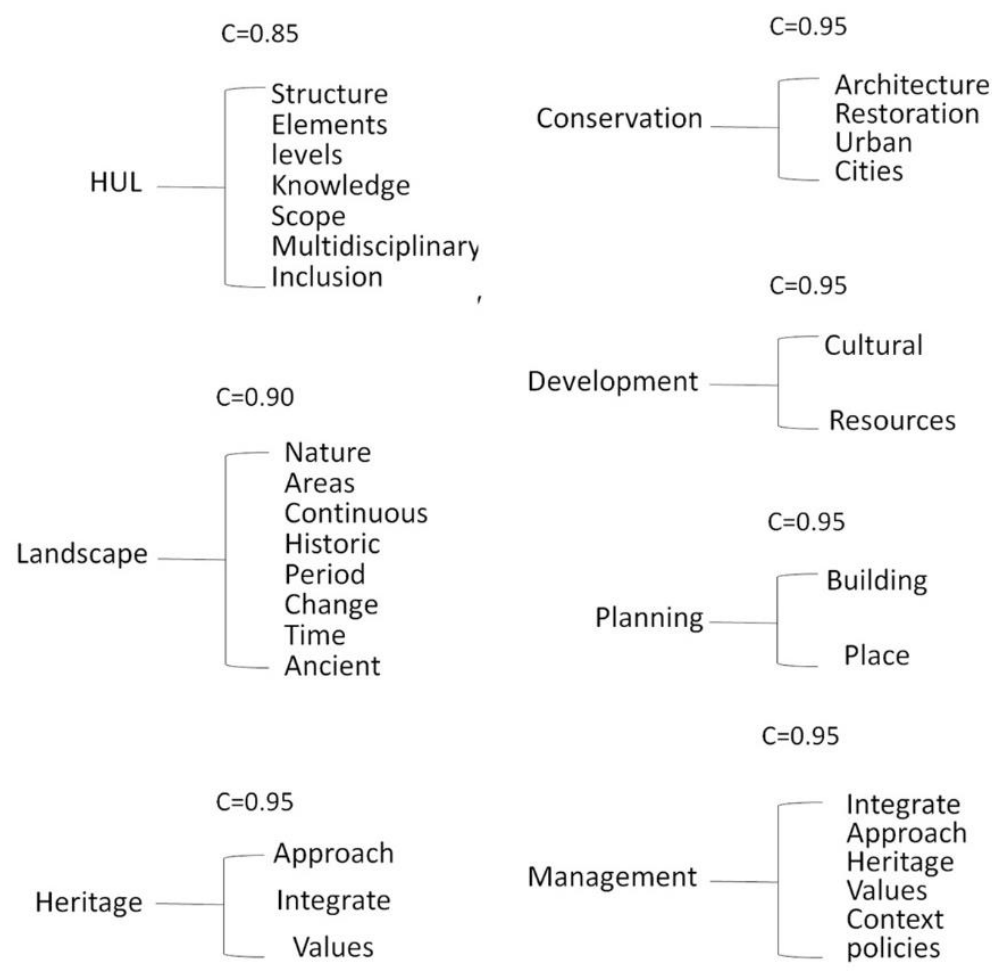

Figure 4. Results of the association analysis.

From the 1990s onwards, the heritage discourse has expanded to include approaches that consider heritage values and are responsive to local cultural contexts rather than focusing on the tangible fabric and technical measures. Notions like value-based approach, all-inclusive approach, landscape approach, integrated approach, holistic approach, people-centred approach, and bottomup approach to heritage are mostly used. These different terminologies have a similar conceptualization that is based on making heritage fully part of the local community. The intensive focus on values is mainly related to the fact that the application of a value-based approach to urban heritage conservation is still a developing inquiry, whereas the tangible and intangible attributes of heritage have a long history in academic research. It is nevertheless worth mentioning that the focus on approaches and heritage values has not eschewed issues of material fabric, as "in many instances material authenticity operates as a guiding principal rather than an absolutist perspective, 
where sites, buildings and objects are made anew in the "heritagisation of contemporary life"" (Winter 2014, 134). Moreover, it has been argued that in practice, a value-based approach appears to increase the power of managing authority in the implementation process and to concentrate mostly on the preservation of the material fabric (Poulios 2010). Furthermore, in the Middle East and North Africa region, conservation practices funded by international organizations such as the World Bank mainly focus on the mobilization of material heritage to foster the economic value of heritage and reduce poverty (Daher 2006; Lafrenz Samuels 2009).

The association analysis of four disciplines: conservation, development, management, and planning shows that even though these fields are among the most frequent terms in the corpus and appear in most publications, they are not highly interrelated. The graph shows that conservation is associated with architecture and restoration, whereas development is associated with cultural resources, and planning with building and place. What is still missing is the link between these three disciplines.

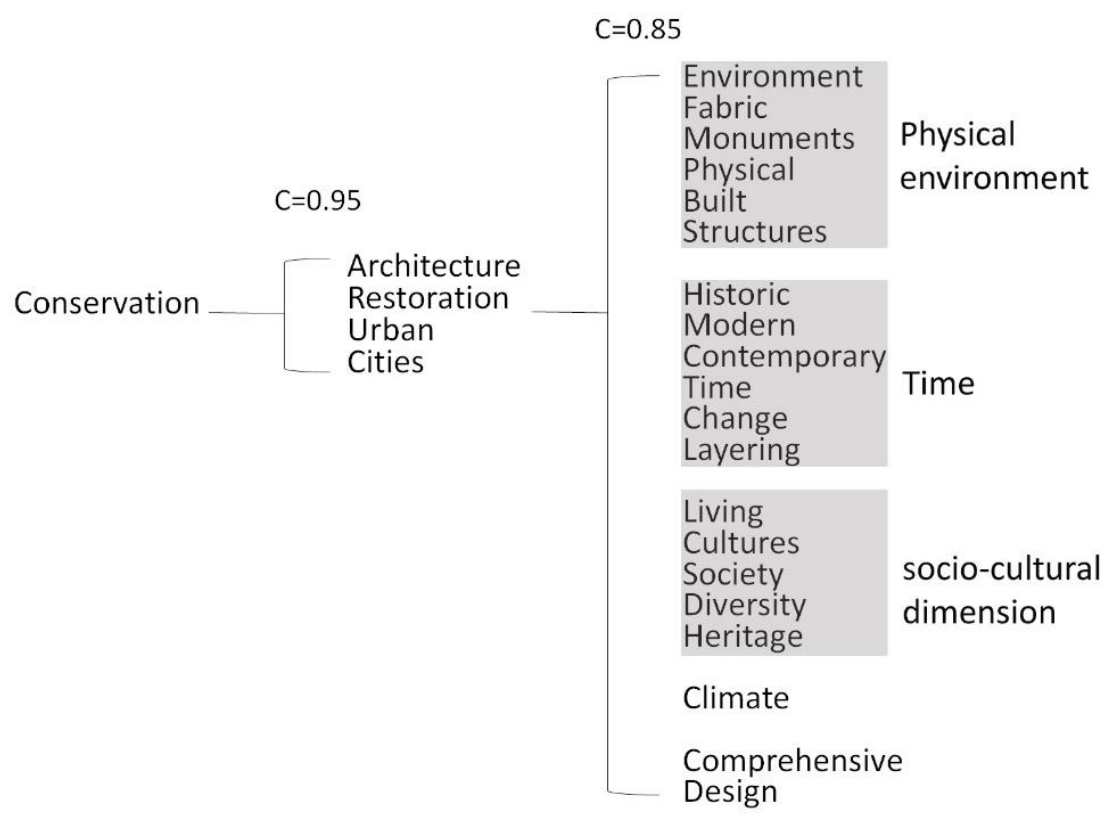

Figure 5. Terms associated with conservation. 
The core of the HUL recommendation remains the integration of conservation and development considerations, but its implementation in its full sense and its translation into local policies is very complicated; the literature on HUL still did not add a great deal in this regard. Figure 5 shows that at a coefficient equal to 0.85 conservation is associated with the physical environment, time, and socio-cultural dimension of heritage as well as climate and comprehensive design. However, the link between theory and practice as well as between conservation and development is missing. Moreover, the analysis shows that management is associated with heritage and that both terms have three commonalities in their results, including approach, integration, and values. This association is a further emphasis on the application of an integrated, value-based approach to heritage management. Two more important terms are associated with management, including context and policies. This association is related to the principle of adapting international guidelines and principles to local context and policies. It should be noted that in many Asian and African cities, most legislative and administrative structures were set up during the European colonial period and were aimed at limited interests (Ndoro and Pwiti 2001). This legislation needs to be updated based on a contextualized approach to protect diverse cultural landscapes. The main argument remains in the possibility of having a global agreement on principles and practices, and of moving from a global to a local level, reflecting the differences in local cultural and values systems as well as the institutionalization of urban heritage management. For instance, the translation alone of international concepts/terms could be a challenge because translation is not a mere linguistic process, but also a cultural one, because language is part of a community's culture (Vermeer 1992). The semantic ambiguity and confusion that arises from the translation of the terms heritage and landscape in the context of Asia and Africa stems from both the different ways these terms could be expressed and interpreted, and from their absence from a 
language, such as the absence of a word corresponding to landscape in Arabic and to heritage in Tamil, Dzongkha, and Pashtu (Makhzoumi 2002; Burenhult and Levinson 2008; Han 2012; Winter and Daly 2012; Van Oers and Pereira Roders 2013).

\subsubsection{Cluster analysis}

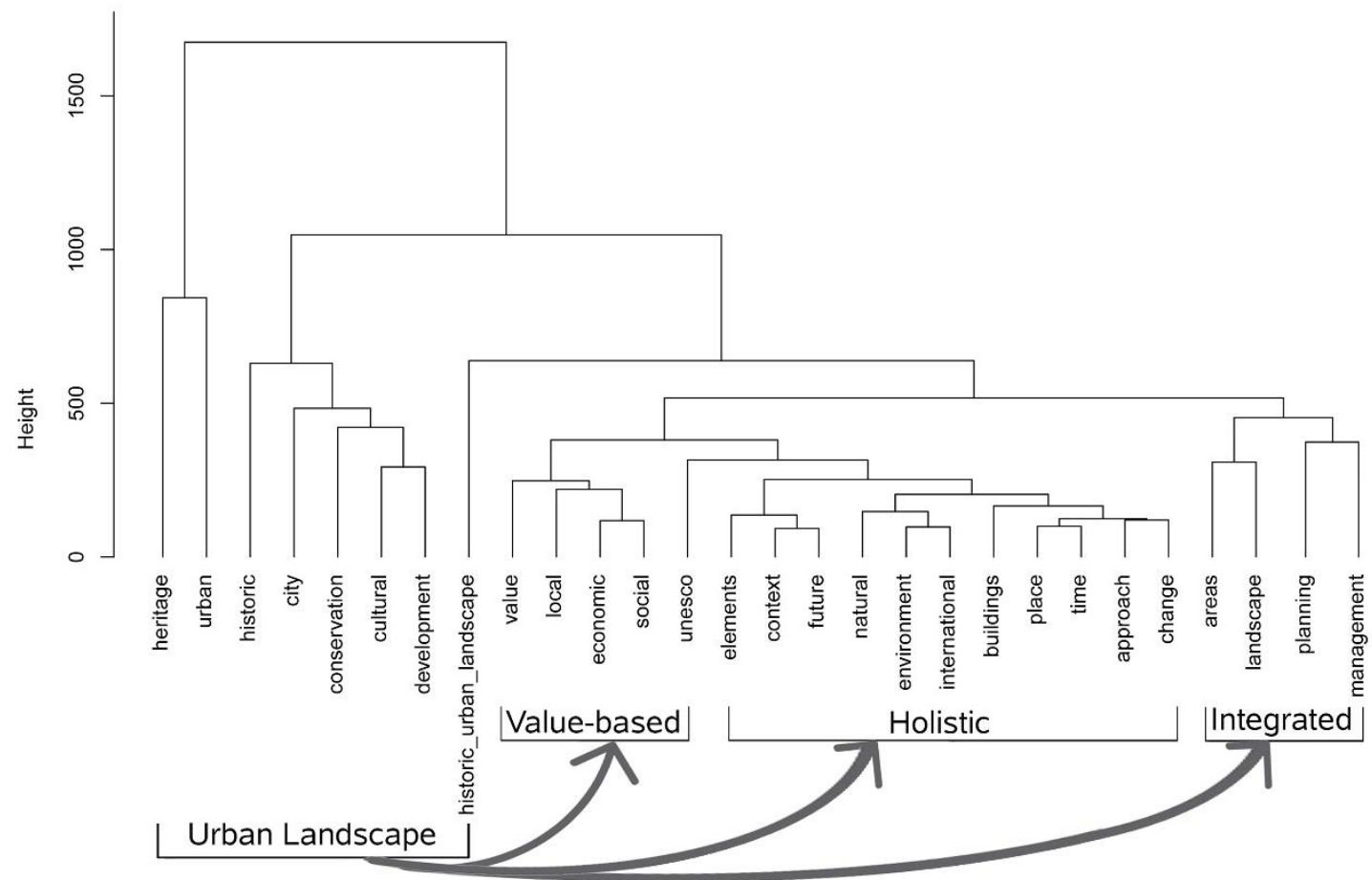

Figure 6. Hierarchal clustering for the corpus of texts.

The vertical axis in this graph is the measure of the closeness of individual terms and clusters. The horizontal axis is not representative of proximity/similarity between terms. In this cluster, observations that are similar are combined into branches which are themselves fused into a cluster at a higher height. The hierarchal clustering of the corpus of texts shows that on the left side, heritage and urban made one small cluster and diffused into a larger one that includes two disciplines: conservation and development, and intangible attributes: historic and cultural. On the 
third level, the HUL is on its own cluster and it is very close to cluster 4, which contains a wide subset of terms that fall into the conceptual approach adopted in this paper (Figure 6).

In cluster 4, the terms elements, context, future, natural, environment, buildings, place, time, and change are clustered at the same level, reflecting the holistic dimension of the HUL. An in-depth reading of this result shows that the application of the HUL to urban heritage conservation and development is discussed in relation to change over time, and to the natural and built attributes of urban context. Urban heritage, instead of being a marginal fragment of the urban landscape, is approached as a model that defines the city and its physical and social pattern. The graph also shows that value is associated with local socio-economic concerns.

The different terms in the deductive cluster diagram can somehow be related to our inductive categorization model. As can be seen from Figure 6, a large number of terms fall under the holistic dimension of the HUL, whereas the integrated and value-based dimensions have almost similar number of terms. The categorization analysis showed that the most discussed dimension in the corpus is the integrated one, followed by the holistic and value-based dimensions. This result means that when the different assets of the HUL are well documented and identified, the operationalization of an integrated and value-based approach is still lacking. The difference between the two graphs (Figure 3 and 6) is that in the first, the different concepts are considered distinctive, while in the second, the terms overlap. For instance, in the cluster diagram, planning, management, place, and values are at the same level, whereas in the developed model management, planning, and value are three main categories, whereas place is a subcategory that falls under landscape and urban design. What is lacking in the deductive graph is assets related to sustainable development processes as well as urban governance in terms of policies, and stakeholders. 


\section{Conclusion}

The HUL recommendation is developing gradually over time. The application process is still in its early stages. A great deal of effort has been devoted to the development of the conceptual framework related to this new approach; most probably because it calls for the integration of different disciplines and considerations that were previously addressed separately. What can be concluded from this analysis is that while the value-based approach is central in HUL conceptualization, its operationalization continues to constitute a challenge, because most discussions about values remain generic and are not fully contextualized in relation to local heritage discourses and the dynamics of heritage governance. Moreover, as the academic discussion is heavily focused on the need to integrate management, conservation, development, and planning disciplines, it does not elaborate much on how to move from theory to practice.

The research also showed that the documentation and analysis of the HULs are applying a holistic approach that combines quantitative and qualitative methods to address the different aspects of the urban landscape. It further showed that the contribution of landscape studies to the conservation of the HUL is not yet fully explored in the corpus of documents. For over a century, these studies have been developing into sophisticated scientific inquiries that, if applied in relation to the conservation and management of urban heritage, would serve to respond to the current orientation of conservation discipline towards an integrated approach that ensures urban sustainability.

In the paradox between universality and locality, we should consider the massive

differences in regulatory and legal systems as well as among institutional bodies in charge of heritage in different states. This results in different levels of adaptation and implementation of the HUL. The regulatory, community engagement, and planning tools could have a significant impact 
on national application of HUL recommendations. A number of case studies have been developed in Global South cities, in contexts where public participation and engagement inherent to the HUL are challenging existing policy and regulatory frameworks. Still, as the HUL is driven by UNESCO, it is sometimes considered as imposed by international bodies and disregarding the specificities of the local context.

The heritage discourse continues to be politicized and reframed according to the different interests of local actors. As Graham (2002) argues, the contested nature of heritage implies that even when heritage is largely defined in the national domain, its management is likely to be conducted at the local scale. Accordingly, discussions about the operationalization of the HUL approach should be grounded in local heritage governance cultures, including processes of heritage identification, conservation, and management, considering the different networks and arenas of governance. This concern is reflected in the six critical steps for its application provided by the HUL recommendation. As this guidance makes clear, the implementation of the HUL depends largely on local management frameworks and levels of coordination between different actors. The adaptation of the HUL to local context and governance culture is certainly a key challenge for its broader application in the field and a deepening of the value-based approach underpinning the recommendation. 


\section{Annex 1}

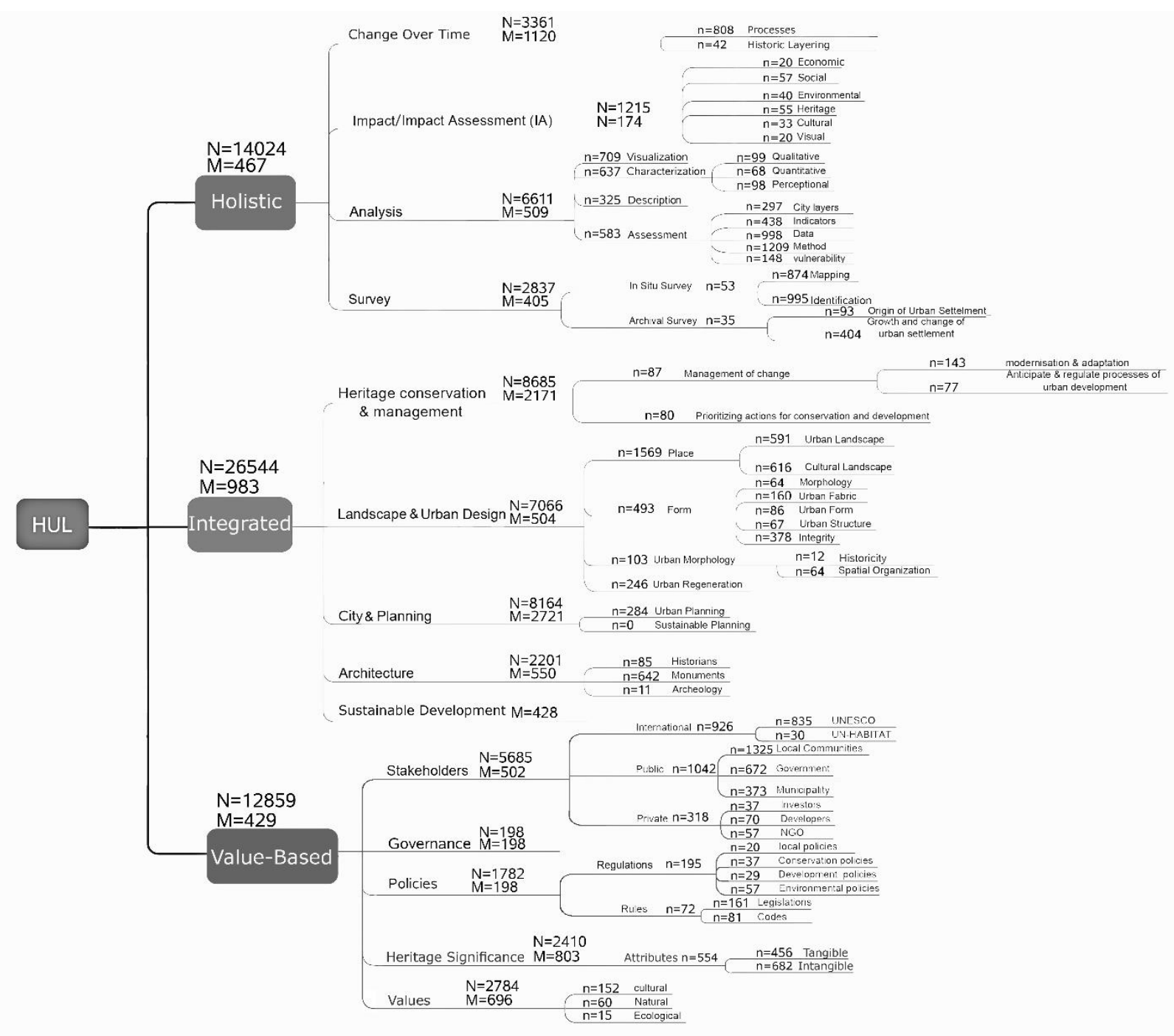

Annex 1. Tree diagram showing the essence of the HUL and the frequency of discussed terms within the corpus of texts. 


\section{References}

Agapiou, A., V. Lysandrou, D. Alexakis, K. Themistocleous, B. Cuca, N. Argyriou, A. Sarris, and D. Hadjimitsis. 2015. "Cultural Heritage Management and Monitoring Using Remote Sensing Data and GIS: The Case Study of Paphos Area, Cyprus." Computers, Environment and Urban Systems 54: 230-239. doi:10.1016/j.compenvurbsys.2015.09.003.

Alves, S. 2015. "Affordances of Historic Urban Landscapes: An Ecological Understanding of Human Interaction with the Past." European Spatial Research and Policy 21 (2): 13-31. doi:10.1515/esrp-2015-0002.

Amoruso, G., and A. Manti. 2016. "A BIM for the Identity of Historic Urban Landscapes. Lntegrated AplicaTions of Survey for the Certosa Di Bologna Architectural Fieritage.” Disegnarecon 9 (16): 17.1-17.7.

Angrisano, M., P. F. Biancamano, M. Bosone, P. Carone, G. Daldanise, F. De Rosa, A. Franciosa, et al. 2016. "Towards Operationalizing UNESCO Recommendations on 'Historic Urban Landscape': A Position Paper.” Aestimum, no. 69: 165-210. doi:10.13128/Aestimum-20454.

Anschuetz, K. F., R. H. Wilshusen, and C. L. Scheick. 2001. "An Archaeology of Landscapes: Perspectives and Directions." Journal of Archaeological Research 9 (2): 157-211. doi:10.1023/A:1016621326415.

Arts, B., M. Buizer, L. Horlings, V. Ingram, C. van Oosten, and P. Opdam. 2017. "Landscape Approaches: A State-of-the-Art Review." Annual Review of Environment and Resources 42 (1): 439-463. doi:10.1146/annurev-environ-102016-060932.

Avrami, E., R. Mason, and M. de la Torre, eds. 2000. Values and Heritage Conservation. Los Angeles, CA: Getty Conservation Institute. http://www.getty.edu/conservation/publications_resources/pdf_publications/values_heritage_rese arch_report.html.

Aysegul, K. T. 2016. "Method for Assessment of the Historical Urban Landscape." Procedia Engineering 161: 1697-1703. doi:10.1016/j.proeng.2016.08.648.

Bahrami, B., and F. Samani. 2015. "Reconnecting the Landscape in Historical Cities, Conceptual Analysis of Historic Urban Landscape Approach in Iran." Current World Environment 10 (2): 456-466. doi:10.12944/CWE.10.2.09.

Bandarin, F. 2015. "Introduction: Urban Conservation and the End of Planning." In Reconnecting the City: The Historic Urban Landscape Approach and the Future of Urban Heritage, edited by F. Bandarin and R. Van Oers, 1-16. Oxford, UK: Wiley-Blackwell.

Bandarin, F., and R. Van Oers. 2012. The Historic Urban Landscape: Managing Heritage in an Urban Century. Oxford, UK: Wiley-Blackwell. 
Bianca, S. 2015. "Morphology as the Study of City Form and Layering." In Reconnecting the City: The Historic Urban Landscape Approach and the Future of Urban Heritage, edited by F. Bandarin and R. Van Oers, 85-111. Oxford, UK: Wiley-Blackwell.

Bolici, R., M. Gambaro, and C. Giordano. 2017. "The Regaining of Public Spaces to Enhance the Historic Urban Landscape.” The Journal of Public Space 2 (Mar. 1): 45. doi:10.5204/jps.v2i1.49.

Bonfantini, G. B. 2015. "Historic Urbanscapes For Tomorrow, Two Italian Cases: Genoa And Bologna.” European Spatial Research and Policy 22 (2): 57-71. doi:10.1515/esrp-2015-0025.

Buckley, K., S. Cooke, and S. Fayad. 2016. "Using the Historic Urban Landscape to Reimagine Ballarat : The Local Context." In Urban Heritage, Development and Sustainability : International Frameworks, National and Local Governance, edited by S. Labadi and W. Logan, 93113. Abingdon: Routledge.

Burenhult, N., and S. C. Levinson. 2008. "Language and Landscape: A CrossLinguistic Perspective.” Language Sciences, Language and Landscape: Geographical Ontology in Cross-Linguistic Perspective 30 (2): 135-150. doi:10.1016/j.langsci.2006.12.028.

Casini, L. 2017. "International Regulation of Historic Buildings and Nationalism: The Role of UNESCO.” Nations and Nationalism 24 (1): 131-147. doi:10.1111/nana.12377.

Cassatella, C., and G. Carlone. 2013. “GIS-Based Visual Analysis for Planning and Designing Historic Urban Landscapes: The Case of Turin.” In 2013 Digital Heritage International Congress (Digitalheritage), 45-52. Marseille, France: IEEE. doi:10.1109/DigitalHeritage.2013.6744728.

Chapagain, N. K. 2013. "Introduction: Contexts and Concerns in Asian Heritage Management." In Asian Heritage Management: Contexts, Concerns, and Prospects, edited by K. D. Silva and N. K. Chapagain, 1-30, Routledge.

Ching Fu, C. 2016. "Conserving Historic Urban Landscape for the Future Generation - Beyond Old Streets Preservation and Cultural Districts Conservation in Taiwan." International Journal of Social Science and Humanity 6 (5): 382-386. doi:10.7763/IJSSH.2016.V6.676.

Ciocia, C., T. Napolitano, and S. Viola. 2013. "Diagnostic Monitoring for Historic Urban Landscape Case Study: Building in via Caracciolo Napoli." European Scientific Journal, ESJ 9 (35). http://eujournal.org/index.php/esj/article/view/2181.

CoE. 1975. "The Declaration of Amsterdam. Council of Europe." Accessed 19 August 2018. http://www.icomos.org/en/support-us/179-articles-enfrancais/ressources/charters-and-standards/169-the-declaration-of-amsterdam.

CoE. 1985. "Convention for the Protection of the Architectural Heritage of Europe." Council of Europe. Accessed 21 August 2018. http://conventions.coe.int/Treaty/en/Treaties/Html/121.htm. 
CoE. 2000. "European Landscape Convention." Florence, Council of Europe. Accessed 19 August 2018. http://conventions.coe.int/Treaty/en/Treaties/Html/176.htm.

CoE. 2005. "Convention on the Value of Cultural Heritage for Society." Council of Europe. Accessed 5 October 2018. https://rm.coe.int/1680083746.

Daher, R. F. 2006. "Tourism, Heritage, and Urban Transformations in Jordan and Lebanon: Emerging Actors and Global-Local Juxtapositions." In Tourism in the Middle East: Continuity, Change and Transformation, edited by R. F. Daher, 263-307. Clevedon, Buffalo: Channel View Publications.

Damen, S. G., R. Derks, T. Metgod, L. Veldpaus, A. T. da Silva, and A. Pereira Roders. 2013. "Relating the State of Authenticity and Integrity and the Factors Affecting World Heritage Properties : Island of Mozambique as Case Study." International Journal of Heritage and Sustainable Development 3 (1): 81-90.

de la Torre, M., eds. 2005. Heritage Values in Site Management: Four Case Studies. Los Angeles, CA: Getty Conservation Institute.

De Rosa, F., and M. Di Palma. 2013. "Historic Urban Landscape Approach and Port Cities Regeneration: Naples between Identity and Outlook." Sustainability 5 (10): 4268-4287. doi:10.3390/su5104268.

Demas, M. 2002. "Planning for Conservation and Management of Archaeological Sites: A ValuesBased Approach." In Management Planning for Archaeological Sites. An International Workshop Organized by the Getty Conservation Institute and Loyola Marymount University, edited by P. Jerome, J. M. Teutonico, and G. Palumbo, 27-54. Vol. 43. Los Angeles, CA: Getty Conservation Institute.

Dhingra, M., M. K. Singh, and S. Chattopadhyay. 2017. "Macro Level Characterization of Historic Urban Landscape: Case Study of Alwar Walled City." City, Culture and Society 9 (June): 39-53. doi:10.1016/j.ccs.2016.10.001.

Dyke, J., A. Neylon, C. Johnston, and L. Honman. 2013. "Mapping Ballarat's Historic Urban Landscape: Stage 1.” Indicative Characterisation Framework. Context Pty.

Fairclough, G., and H. Londen. 2010. "Changing Landscapes of Archeology and Heritage.” In The Cultural Landscape \& Heritage Paradox: Protection and Development of the Dutch Archaeological-Historical Landscape and Its European Dimension, edited by T. Bloemers, H. Kars, and A. Van der Valk, 653-669, Amsterdam University Press.

Forman, R. T. 1995. Land Mosaics: The Ecology of Landscapes and Regions. Cambridge University Press.

Gabrielli, B. 2010. "Urban Planning Challenged by Historic Urban Landscape." In Managing Historic Cities, edited by R. van Oers, 19-26. Paris, France: UNESCO, World Heritage Centre. 
Getimis, P., and G. Kafkalas. 2002. "Empirical Evidence and Comparative Analysis of PolicyMaking in the Pursuit of Innovation and Sustainability." In Participatory Governance in MultiLevel Context: Concepts and Experience, edited by H. Heinelt, P. Getimis, G. Kafkalas, R. Smith, and E. Swyngedouw, 155-171. Wiesbaden: VS Verlag für Sozialwissenschaften. doi:10.1007/978-3-663-11005-7_8.

Giaccardi, E. 2012. "Heritage and Social Media: Understanding Heritage in a Participatory Culture." In Reframing Heritage in a Participatory Culture. 1st ed. edited by E. Giaccardi, 110. New York: Routledge.

Ginzarly, M., A. Pereira Roders, and J. Teller. Forthcoming. "Mapping Historic Urban Landscape Values through Social Media.” Journal of Cultural Heritage. doi:10.1016/j.culher.2018.10.002.

Ginzarly, M., and J. Teller. 2018. "Eliciting Cultural Heritage Values: Landscape Preferences Vs Representative Images of the City." Journal of Cultural Heritage Management and Sustainable Development 8 (3): 257-275. doi:10.1108/JCHMSD-06-2017-0031.

Girard, L. 2013. "Toward a Smart Sustainable Development of Port Cities/Areas: The Role of the 'Historic Urban Landscape' Approach.” Sustainability 5 (10): 4329-4348. doi:10.3390/su5104329.

Gobster, P. H., J. I. Nassauer, T. C. Daniel, and G. Fry. 2007. "The Shared Landscape: What Does Aesthetics Have to Do with Ecology?” Landscape Ecology 22 (7): 959-972. doi:10.1007/s10980007-9110-x.

Graham, B. 2002. "Heritage as Knowledge: Capital or Culture?" Urban Studies 39 (5-6): 10031017. doi:10.1080/00420980220128426.

Gunay, Z. 2018. “A Critical Appraisal on Turkey's Neoliberal Quest of Urban Renewal in Historic Urban Landscapes.” In Living under the Threat of Earthquakes, 129-141. Cham: Springer Natural Hazards. Springer. doi:10.1007/978-3-319-68044-6_9.

Han, F. 2012. "Cultural Landscape: A Chinese Way of Seeing Nature." Managing Cultural Landscapes. February 13: 2012. doi:10.4324/9780203128190-14.

Heathcott, J. 2013. "Historic Urban Landscapes of the Swahili Coast: New Frameworks for Conservation." In Swahili Historic Urban Landscapes, edited by R. Van Oers and S. Haraguchi, 20-39. Paris, France: UNESCO.

Heras, V. C., A. Wijffels, F. Cardoso, A. Vandesande, M. Santana, J. Van Orshoven, T. Steenberghen, and K. van Balen. 2013. "A Value-Based Monitoring System to Support Heritage Conservation Planning." Journal of Cultural Heritage Management and Sustainable Development 3 (2): 130-147. doi:10.1108/JCHMSD-10-2012-0051.

Hill, M. J., and M. Tanaka. 2015. "Entrepreneurial Heritage: Historic Urban Landscapes and the Politics of 'Comprehensive Development' in Post-Soviet Cuba." In Urban Heritage, Development 
and Sustainability: International Frameworks, National and Local Governance, edited by S. Labadi and W. Logan, 214-231. Abingdon: Routledge.

Hosagrahar, J. 2013. "Recommendation on Historic Urban Landscapes: Relevance in India." Context 10 (2): 19-26.

Hosagrahar, J. 2015. "Knowledge and Planning Tools." In Reconnecting the City: The Historic Urban Landscape Approach and the Future of Urban Heritage, 249-268. WileyBlackwell. doi:10.1002/9781118383940.ch10.

ICOMOS. 1987. "Charter for the Conservation of Historic Towns and Urban Areas Washington Charter." ICOMOS. Accessed 10 August 2018. https://www.icomos.org/en/what-wedo/focus/179-articlesen-francais/ressources/charters-and-standards/159-charter-for-theconservation-of-historic-towns-and-urban-areas.

ICOMOS. 2005. "Xi' an Declaration on the Conservation of the Setting of Heritage Structures, Sites and Areas." Xi'an, China: ICOMOS. Accessed 10 August 2018. http://www.icomos.org/xian2005/xiandeclaration.htm.

ICOMOS. 2011. "The Valletta Principles for the Safeguarding and Management of Historic Cities, Towns and Urban Areas Principles De La Valette Po."

ICOMOS. Accessed 12 August 2018. http://www.international.icomos.org/Paris2011/GA2011 CIVVIH_text_EN_FR_final_20120110.pdf.

ICOMOS Australia. 1999. "The Charter for Places of Cultural Significance." ICOMOS Australia. Accessed 12 August 2018. http://www.heritage.tas.gov.au/media/pdf/The\%20Burra\% 20Charter\%201999adopted.pdf.

Jessiman, S. 2015. "Challenges for Implementing UNESCO's Historic Urban Landscape Recommendation in Canada." In Urban Heritage, Development and Sustainability: International Frameworks, National and Local Governance, edited by S. Labadi and W. Logan, 8092. Abingdon: Routledge.

Lafrenz Samuels, K. 2009. "Trajectories of Development: International Heritage Management of Archaeology in the Middle East and North Africa." Archaeologies 5 (1): 68-91. doi:10.1007/s11759-008-9092-6.

Lascu, L. F. 2014. "Identification and Interpretation of the Historical Dimension of Urban Landscape. Case Study: The Historical Centre of Bucharest." International Journal of Academic Research in Environment and Geography 1 (2): 40-45.

Liew, C. L. 2014. “Participatory Cultural Heritage: A Tale of Two Institutions' Use of Social Media.” D-Lib Magazine 20 (3/4). doi:10.1045/march2014-liew. 
Logan, W. 2012. "States, Governance and the Politics of Culture: World Heritage in Asia." In Routledge Handbook of Heritage in Asia, edited by P. Daly and T. Winter, 113128. UK: Routledge, Abingdon. doi:10.4324/9780203156001-15.

Makhzoumi, J. M. 2002. "Landscape in the Middle East: An Inquiry." Landscape Research 27 (3): 213-228. doi:10.1080/01426390220149494.

Markevičienè, J. 2011. "Protection of Human Rights to the City and Preservation of Historic Urban Landscapes: Ways to Coherence." Town Planning and Architecture 35 (4): 301-309. doi:10.3846/tpa.2011.32.

Martin, G. J., and P. E. James. 1981. All Possible Worlds: A History of Geographical Ideas. 2d ed, NewYork: Wiley.

Masi, A. D. 2015. "Documentation, Digital Survey and Protection for a Multidisciplinary Knowledge of Some Urban Historic Landscape in Italy." In Engineering Geology for Society and Territory, Vol. 8, 351-356. Cham: Springer. doi:10.1007/978-3-319-09408-3_61.

Mason, R. 2002. "Assessing Values in Conservation Planning: Methodological Issues and Choices." In Assessing the Values of Cultural Heritage, edited by M. De la Torre, 5-30. Los Angeles, CA: Getty Conservation Institute.

Mason, R., and E. Avrami. 2002. "Heritage Values and Challenges of Conservation Planning." In Management Planning for Archaeological Sites: An International Workshop, edited by J. M. Teutónico and G. Palumbo, 13-26. Los Angeles, CA: Getty Conservation Institute.

Mostafavi, M., and C. Najle. 2004. Landscape Urbanism: A Manual for the Machinic Landscape. London: AA Publications.

Murphy, A., P. Dahlhaus, and H. Thompson. 2016. "Historic Urban Landscapes and Visualising Ballarat : Citizen Participation for Sustainable Urban Planning and Design." In The 3rd Annual Conference of Research@Locate, 41-46. Melbourne, Australia: CEUR-WS.

Ndoro, W., and G. Pwiti. 2001. "Heritage Management in Southern Africa: Local, National and International Discourse.” Public Archaeology 2 (1): 21-34. doi:10.1179/pua.2001.2.1.21.

Nocca, F. 2017. "Hybrid evaluation tools for operationalizing UNESCO Historic Urban Landscape Approach.” Department of Architecture, University of Naples Federico II.

O’Donnell, P. 2015. "The Role of Regulatory Systems.” In Reconnecting the City: The Historic Urban Landscape Approach and the Future of Urban Heritage, 269-281. WileyBlackwell. doi:10.1002/9781118383940.ch11.

O’Donnell, P., and M. Turner. 2012. The Historic Urban Landscape Recommendation: A New UNESCO Tool for A Sustainable Future. Cape Town: IFLA. 
Ole, S. I., and R. C. Smith. 2012. "Connecting to Everyday Practices: Experineces from the Digital Natives Exhibition." In Heritage and Social Media: Understanding Heritage in a Participatory Culture, edited by E. Giaccardi, 69-86. 1st ed. New York: Routledge.

Panjabi, S., and T. Winter. 2009. "Understanding the Tensions in Place - Conflict and Conservation in Kashmir." Historic Environment 22 (1): 19-25.

Pereira Roders, A. 2013. "Lessons from the Island of Mozambique on Limits of Acceptable Change." In Swahili Historic Urban Landscapes, edited by R. Van Oers and S. Haraguchi, 4049. Paris, France: UNESCO.

Potdar, K., N. Namrata, and A. Sami. 2018."Nature, Culture and Humans: Patterns and Effects of Urbanization in Lesser Himalayan Mountainous Historic Urban Landscape of Chamba, India.” Journal of Heritage Management. March. doi:10.1177/2455929617736395.

Poulios, I. 2010. "Moving beyond a Values-Based Approach to Heritage Conservation." Conservation and Management of Archaeological Sites 12 (2): 170-185. doi:10.1179/175355210X12792909186539.

Poulios, I. 2014. Past in the Present: A Living Heritage Approach - Meteora, Greece. London: Ubiquity Press.

Ragozino, S. 2016. "Tools for Regeneration of the Urban Landscape Social Enterprise as a Link between People and Landscape." Procedia - Social and Behavioral Sciences, , 223 (Jun.): 201208. doi:10.1016/j.sbspro.2016.05.349.

Redford, K. H., P. Coppolillo, E. W. Sanderson, G. A. B. Da Fonseca, E. Dinerstein, C. Groves, G. Mace, et al. 2003. "Mapping the Conservation Landscape." Conservation Biology 17 (1): 116-131. doi:10.1046/j.15231739.2003.01467.x.

Rey-Perez, J., and P. G. Martinez. 2018. "Lights and Shadows over the Recommendation on the Historic Urban Landscape: Managing Change in Ballarat and Cuenca through a Radical Approach Focused on Values and Authenticity." International Journal of Heritage Studies 24 (1): 101-116. doi:10.1080/13527258.2017.1362572.

Rey-Perez, J., and M. Siguencia Avila. 2017. "Historic Urban Landscape: An Approach for Sustainable Management in Cuenca (Ecuador)." Journal of Cultural Heritage Management and Sustainable Development 7 (3): 308-327. doi:10.1108/JCHMSD-12-2016-0064.

Riegl, A. 1903. The Modern Cult of Monuments: Its Character and Origin. Translated and edited by Kurt W. Forster and Diane Ghirardo, in Oppositions, n. 25 (Fall 1982), 21-51.

Rinaudo, F., E. Agosto, and P. Ardissone. 2007. "GIS and WEB-GIS, Commercial and Open Source Platforms: General Rules for Cultural Heritage Documentation." Paper presented at the XXI International CIPA Symposium, Athens, Greece, October 1-6. 
Ripp, M., and D. Rodwell. 2018. "Governance in UNESCO World Heritage Sites: Reframing the Role of Management Plans as a Tool to Improve Community Engagement." In Aspects of Management Planning for Cultural World Heritage Sites, 241-253. Cham: Springer. doi:10.1007/978-3-319-69856-4_18.

Robinson, M. H., C. R. Alexander, C. W. Jackson, C. P. McCabe, and D. Crass. 2010. "Threatened Archaeological, Historic, and Cultural Resources of the Georgia Coast: Identification, Prioritization and Management Using GIS Technology.” Geoarchaeology 25 (3): 312-326. doi:10.1002/gea.20309.

Rodwell, D. 2010. "Historic Urban Landscapes: Concept and Management." In Managing Historic Cities, edited by R. van Oers, 99-104. Paris, France: UNESCO, World Heritage Centre. http://unesdoc.unesco.org/Ulis/cgibin/ulis.pl?catno=211912\&set=0057F86E04_1_189\&gp=0\&li $\underline{\mathrm{n}=1 \& l \mathrm{l}=\mathrm{s}}$.

Rogers, A. P. 2014. "Rawalpindi Historic Urban Landscape Project." https://www.academia.edu/10585632/Rawalpindi_Historic_Urban_Landscape_Project.

Rypkema, D. 2015. "Devising Financial Tools for Urban Conservation." In Reconnecting the City: The Historic Urban Landscape Approach and the Future of Urban Heritage, 283-300. WileyBlackwell. doi:10.1002/9781118383940.ch12.

Sanjbod, H. S., L. Hermans, D. Reijnders, and L. Veldpaus. 2016. "Captain, Where Can We Find the Attributes?" The Historic Environment: Policy \& Practice 7 (2-3): 177-188. doi:10.1080/17567505.2016.1172786.

Shamsuddin, S., A. B. Sulaiman, and R. C. Amat. 2012. "Urban Landscape Factors that Influenced the Character of George Town, Penang Unesco World Heritage Site." Procedia - Social and Behavioral Sciences, , 50 (January): 238-253. doi:10.1016/j.sbspro.2012.08.031.

Siguencia Avila, M. 2018. "The Historic Urban Landscape (HUL) approach for the conservation of the Historic Centre of Cuenca-Ecuador.”, Katholieke Universiteit Leuven.

Siguencia Avila, M., and J. Rey-Perez. 2016. "Heritage Values Protection, from the Monument to the Urban Dimension. Case Study: The Historic Centre of Santa Ana De Los Ríos De Cuenca, Ecuador." The Historic Environment: Policy \& Practice 7 (2-3): 164-176. doi:10.1080/17567505.2016.1172785.

Smith, J. 2010. "Marrying the Old with the New in Historic Urban Landscapes." In Managing Historic Cities, edited by R. van Oers, 45-52. Paris, France: UNESCO, World Heritage Centre. http://unesdoc.unesco.org/Ulis/cgibin/ulis.pl?catno=211912\&set=0057F86E04_1_189\&g $\mathrm{p}=0 \& \operatorname{lin}=1 \& l 1=\mathrm{s}$.

Smith, J. 2015. "Civic Engagement Tools for Urban Conservation." In Reconnecting the City: The Historic Urban Landscape Approach and the Future of Urban Heritage, 221-248. WileyBlackwell. doi:10.1002/9781118383940.ch9. 
Smith, L. 2007. “General Introduction.” In Cultural Heritage: Critical Concepts in Media and Cultural Studies, edited by I. Laurajane Smith, Hitsory and concepts, 1-21. Routledge.

Smith, L., and N. Akagawa. 2008. "Introduction." In Intangible Heritage, edited by L. Smith and N. Akagawa. Routledge.

Spirn, A. 1998. The Language of Landscape. New Haven: Yale University Press.

Stephenson, J. 2008. "The Cultural Values Model: An Integrated Approach to Values in Landscapes." Landscape and Urban Planning 84 (2): 127-139. doi:10.1016/j.landurbplan.2007.07.003.

Swyngedouw, E. 2005. "Governance Innovation and the Citizen: The Janus Face of Governancebeyond-The-State.” Urban Studies 42 (11): 1991-2006. doi:10.1080/00420980500279869.

Sykes, O., and C. Ludwig. 2015. "Defining And Managing The Historic Urban Landscape: Reflections On The English Experience And Some Stories From Liverpool.” European Spatial Research and Policy 22 (2): 9-35. doi:10.1515/esrp-2015-0023.

Taylor, K. 2015. "Cities as Cultural Landscapes." In Reconnecting the City: The Historic Urban Landscape Approach and the Future of Urban Heritage, edited by F. Bandarin and R. Van Oers, 179-202, Wiley-Blackwell.

Taylor, K. 2016. "The Historic Urban Landscape Paradigm and Cities as Cultural Landscapes. Challenging Orthodoxy in Urban Conservation." Landscape Research 41 (4): 471-480. doi:10.1080/01426397.2016.1156066.

Terkenli, T. 2001. "Towards a Theory of the Landscape: The Aegean Landscape as a Cultural Image.” Landscape Urban Planning 57: 197-208. doi:10.1016/S0169-2046(01)002043.

Terras, M. 2011. "The Digital Wunderkammer: Flickr as a Platform for Amateur Cultural and Heritage Content.” Library Trends 59 (4): 686-706. doi:10.1353/lib.2011.0022.

Thompson, C. W. 2013. "Landscape Perception and Environmental Psychology." In The Routledge Companion to Landscape Studies, edited by P. Howard, I. Thompson, and E. Waterton, 25-42. Abingdon: Routledge. doi:10.4324/9780203096925.

Thompson, I., P. Howard, and E. Waterton. 2013. "Introduction." In The Routledge Companion to Landscape Studies, edited by P. Howard, I. Thompson, and E. Waterton, 17. Abingdon: Routledge. doi:10.4324/9780203096925.

Tress, B., and G. Tress. 2001. "Capitalising on Multiplicity: A Transdisciplinary Systems Approach to Landscape Research." Landscape and Urban Planning 57: 143-157. doi:10.1016/S0169-2046(01)00200-6. 
Tress, B., G. Tress, H. Décamps, and A.-M. d'Hauteserre. 2001. "Bridging Human and Natural Sciences in Landscape Research." Landscape and Urban Planning 57 (3-4): 137-141. doi:10.1016/S0169-2046(01)00199-2.

Trindade-Chagas, N. 2011. "The Conceptual Proximity between Cultural Landscape and Historic Urban Landscape." In The International Conference on World Heritage: The Significance of World Heritage: Origins, Management, Consequences, 76-94. Falun, Sweden: Dalarna University, WHILD.

UNESCO. 1972. "Convention Concerning the Protection of the World Cultural and Natural Heritage.” Accessed 20 August 2018. http://whc.unesco.org/en/conventiontext.

UNESCO. 1976. "Recommendation Concerning the Safeguarding and Contemporary Role of Historic Areas." Accessed 18 August 2018. http://portal.unesco.org/en/ev.phpURL_ID=13133\&URL_DO=DO_TOPIC\&URL_SECTION=201.html.

UNESCO. 1994. "The Nara Document on Authenticity." Accessed 18 August 2018. https://whc.unesco.org/archive/nara94.htm.

UNESCO. 1999. "Operational Guidelines for the Implementation of the World Heritage Convention.” Accessed 25 August 2018. https://whc.unesco.org/archive/opguide99.pdf.

UNESCO. 2003. "Convention for the Safeguarding of the Intangible Cultural Heritage." Paris: UNESCO World Heritage Centre. Accessed 30 July 2018. http://unesdoc.unesco.org/images/0013/001325/132540e.pdf.

UNESCO. 2005. "Vienna Memorandum on 'World Heritage and Contemporary Architecture Managing the Historic Urban Landscape'." Accessed 20 August 2018. http://whc.unesco.org/document/6814.

UNESCO. 2011. Recommendation on the Historic Urban Landscape. Paris: UNESCO World Heritage

Centre. Accessed 10 February 2018. https://whc.unesco.org/uploads/activities/documents/activit y-638-98.pdf.

UNESCO. 2016. The HUL Guidebook: Managing Heritage in Dynamic and Constantly Changing Urban Environments. WHITRAP and City of Ballarat, online resource. http://www.hulballarat.org.au/resources/HUL\%20Guidebook_2016_FINALWEB.pdf.

Van Oers, R. 2010. "Managing Cities and the Historic Urban Landscape Initiative - an Introduction." In Managing Historic Cities, edited by R. van Oers, 7-17. Paris, France: UNESCO, World Heritage Centre.

Van Oers, R. 2013. "Swahili Pilot Cities for HUL Application." In Swahili Historic Urban Landscapes, edited by R. Van Oers and S. Haraguchi, 64-112. Paris, France: UNESCO. 
Van Oers, R. 2015. "Conclusion: The Way Forward: An Agenda for Reconnecting the City." In Reconnecting the City: The Historic Urban Landscape Approach and the Future of Urban Heritage, edited by F. Bandarin and R. Van Oers, 317-327. Oxford, UK: Wiley-Blackwell.

Van Oers, R., and A. Perira Roders. 2013. "Road Map for Application of the HUL Approach in China." Journal of Cultural Heritage Management and Sustainable Development 3 (1): 4-17. doi:10.1108/JCHMSD-01-2013-0002.

Veldpaus, L. 2015. "Historic Urban Landscapes: Framing the Integration of Urban and Heritage Planning in Multilevel Governance.", Eindhoven University of Technology.

Veldpaus, L., and A. Pereira Roders. 2017. "Historic Urban Landscape Approach as a Tool for Sustainable Urban Heritage Management." In Culture in Sustainability: Towards a Transdiciplinary Approach, edited by S. Asikainen, C. Brites, K. Plebańczyk, R. Mijatović, and K. Soini Jyväskylä, 62-74. Jyväskylä: University of Jyväskylä, Department of Social Sciences and Philosophy.

Veldpaus, L., A. Pereira Roders, and B. Colenbrander. 2013. "Urban Heritage: Putting the past into the Future." The Historic Environment: Policy \& Practice 4 (1): 3-18. doi:10.1179/1756750513Z.00000000022.

Verdini, G., F. Frassoldati, and C. Nolf. 2017. "Reframing China's Heritage Conservation Discourse. Learning by Testing Civic Engagement Tools in a Historic Rural Village." International Journal of Heritage Studies 23 (4): 317-334. doi:10.1080/13527258.2016.1269358.

Vermeer, H. 1992. "Is Translation a Linguistic or a Cultural Process?.” Ilha Do Desterro A Journal of English Language, Literatures in English and Cultural Studies, no. 28: 037-051.

Waldheim, C. 2006. The Landscape Urbanism Reader. Princeton Architectural Press.

Wang, G. 2014. "Conserving Historic Urban Landscape and Beautifying the City by Means of Its History." Conservation Science in Cultural Heritage 14 (2): 13-32. doi:10.6092/issn.19739494/5438.

Weiss, L. M. 2014. "Informal Settlements and Urban Heritage Landscapes in South Africa." Journal of Social Archaeology 14 (1): 3-25. doi:10.1177/1469605313519023.

Whitehand, J., and K. Gu. 2010. "Conserving Urban Landscape Heritage: A Geographical Approach." Procedia - Social and Behavioral Sciences, , 2 (5): 6948-6953. doi:10.1016/j.sbspro.2010.05.047.

Widodo, J., Y. C. Wong, and F. Ismail. 2017. "Digital Historic Urban Landscape Methodology for Heritage Impact Assessment of Singapore." ISPRS Annals of Photogrammetry, Remote Sensing and Spatial Information Sciences IV-2/W2: 327-334. doi:10.5194/isprs-annals-IV-2-W2-3272017. 
Willems, W. 2014. "Laws, Language, and Learning Managing Archaeological Heritage Resources in Europe." In Cultural Heritage Management: A Global Perspective, edited by P. M. Messenger and G. S. Smith, 212-229. Reprint ed. Gainesville: University Press of Florida.

Williams, T. 2015. "Archaeology: Reading the City through Time." In Reconnecting the City: The Historic Urban Landscape Approach and the Future of Urban Heritage, 17-45. WileyBlackwell. doi:10.1002/9781118383940.ch1.

Winter, T. 2014. "Beyond Eurocentrism? Heritage Conservation and the Politics of Difference." International Journal of Heritage Studies 20 (2): 123-137. doi:10.1080/13527258.2012.736403.

Winter, T., and P. Daly. 2012. "Routledge Handbook of Heritage in Asia." In Heritage in Asia: Converging Forces, Conflicting Values, edited by T. Winter and P. Daly, 135. 1st ed. London: Routledge.

Wu, J., and R. Hobbs. 2002. "Key Issues and Research Priorities in Landscape Ecology: An Idiosyncratic Synthesis." Landscape Ecology 17 (4): 355-365. doi:10.1023/A:1020561630963. 